Cristiane Fátima Dias de Jesus

Afecções de Pele: Uma Pele para Dois?

DISSERTAÇÃO DE MESTRADO

DEPARTAMENTO DE PSICOLOGIA

Programa de Pós-Graduação em Psicologia Clínica

Rio de Janeiro Janeiro de 2004 
Pontifícia U Universidade Católlica $_{\text {Do }}$

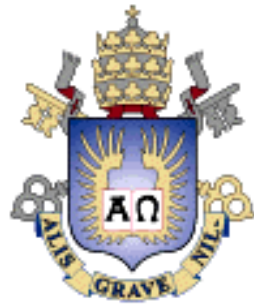

Cristiane Fátima Dias de Jesus

Afecções de Pele: Uma Pele para Dois?

Dissertação de Mestrado

Dissertação apresentada ao Programa de PósGraduação em Psicologia Clínica do Departamento de Psicologia da PUC-Rio como parte dos requisitos parciais para a obtenção do grau de mestre em Psicologia.

Orientador: Maria Helena Novaes Mira

Rio de Janeiro

Janeiro de 2004 
Cristiane Fátima Dias de Jesus

\section{Afecções de Pele: Uma Pele para Dois?}

Dissertação apresentada como requisito parcial para obtenção do grau de Mestre pelo Programa de Pós-Graduação em Psicologia Clínica do Departamento de Psicologia do Centro de Teologia e Ciências Humanas da PUC-Rio. Aprovada pela Comissão Examinadora abaixo assinada.

Profa $^{a}$. Maria Helena Novaes Mira

Orientadora

Departamento de Psicologia - PUC-Rio

Profa. Flávia Sollero de Campos Departamento de Psicologia - PUC-Rio

Prof $^{\mathrm{a}}$ Maria Luiza T. de A. Lo Presti Seminerio Instituto de Psicologia - UFRJ

Prof. Paulo Fernando Carneiro de Andrade Coordenador setorial de Pós-Graduação

E Pesquisa do Centro de Teologia e

Ciências Humanas - PUC-Rio

Rio de Janeiro, / / 2004. 
Todos os direitos reservados. É proibida a reprodução total ou parcial do trabalho sem autorização da universidade, da autora e do orientador.

Cristiane Fátima Dias de Jesus

Graduou-se em Psicologia pela Faculdade de Psicologia e Ciências da Educação da Universidade do Porto-Portugal em 1996. Especializou-se em Terapia Familiar Sistêmica em 2001pela Núcleo Pesquisas. Trabalhou no Instituto da Família (INFA), tendo participado do planejamento e execução de projetos comunitários de saúde. Desde então vêm exercendo clínica individual e vincular (casal, família) tanto no contexto privado como no contexto comunitário.

Ficha catalográfica

JESUS, Cristiane Fátima Dias de

Afecções de pele: Uma pele para dois ?/ Cristiane Fátima Dias de Jesus; orientadora: Maria Helena Novaes Mira. - Rio de Janeiro: PUC; Departamento de Psicologia, 2004.

$107 p$.

1.Dissertação (Mestrado) - Pontifícia Universidade Católica do Rio de Janeiro, Departamento de Psicologia

Inclui referências bibliográficas.

1.Psicologia - Dissertação. 2. Afecções de pele: Uma pele para dois 3. Afecções de pele. 4 Holding. 5. Separaçãoindividualização. 6. Interação mão-bebê 7. Limites corporais. I. Mira, Maria Helena Novaes. II Pontifícia Universidade Católica do Rio de Janeiro. Departamento de Psicologia. III. Título. 


\section{Agradecimentos}

À minha orientadora Professora Maria Helena Novaes Mira pela compreensão nos momentos difíceis, pela conduta ética e parceria na realização deste trabalho.

À CAPES e à PUC-Rio, pelos auxílios concedidos, sem os quais este trabalho não teria sido possível.

À minha Professora Ângela Baraf Podkameni pelas importantes contribuições concedidas, por todo carinho e atenção.

Aos meus colegas da PUC-Rio.

A todos os professores e funcionários do Departamento de Psicologia, pela ajuda sempre valorosa.

Aos meus pais, pelo carinho e pelo apoio que me prestaram durante este percurso. 


\section{Resumo}

Jesus, Cristiane Fátima Dias de. Afecções de pele: Uma pele para dois? Rio de Janeiro, 2003. 107 p. Dissertação de Mestrado - Departamento de Psicologia, Pontifícia Universidade Católica do Rio de Janeiro.

A pele tem uma importância fundamental na nossa constituição psíquica. Através dos primeiros contatos de pele com a mãe ou ambiente maternante o bebê começa a formar as mais primitivas impressões acerca do corpo que lhe pertence e do mundo que o rodeia. Este estudo pretende mostrar que as afecções de pele refletem um desejo de retorno ou permanência no estado de indiferenciação com a mãe. Deste modo, parte-se do princípio que distorções no elo mãe-filho desde cedo não permitem ao mesmo vivenciar com naturalidade seu trajeto rumo à independência, nos termos de Winnicott, ou em direção à individuação, de acordo com Mahler. A falta de um ambiente "bom o bastante" dificulta a aquisição de uma experiência subjetiva de corpo. Por outro lado, abordam-se também os pressupostos da Escola de Psicossomática de Paris, segundo a qual, os processos que levam à vulnerabilidade psicossomática também estariam relacionados à falhas na estruturação desta ligação, resultando na insuficiência e/ ou desorganização das funções psíquicas. Portanto, com este objetivo pretende-se mostrar que as afecções de pele refletem uma falha nos processos de delimitação das fronteiras do corpo pela falta ou inadequação do investimento materno nos primeiros anos de vida, dificultando a experiência de unidade e coesão de seus processos internos e externos. Na parte final, procede-se à discussão de um caso clínico à luz das teorias anteriormente mencionadas.

\section{Palavras-chave}

Afecções de pele; holding; separação-individuação; interação mãe-bebê; limites corporais. 


\section{Abstract}

Jesus, Cristiane Fátima Dias de Jesus. Skin disorders: One skin for two? Rio de Janeiro, 2003.107 p. Msc. Dissertation - Departamento de Psicologia, Pontifícia Universidade Católica do Rio de Janeiro.

The skin is of basic importance to our psychic constitution. Through the first skin contacts with the mother or mothering environment the baby starts to form the most primitive impressions concerning the body that belongs to him/her as well as the world that surrounds it. This study intends to show that skin disorders reflect the desire of a return or permanence in the state of indiferenciation with the mother. In this way, based on distortions in the early mother-baby link, the child is not allowed to naturally live his passage towards independence, as per Winnicott, or towards individuation, according to Mahler. The lack of a "good enough environment" makes the acquisition of a subjective body experience difficult. On the other hand, principles of the school of psychoanalytic psychosomatics of Paris were used, according to which processes that lead to the psychosomatic vulnerability would also be related to imperfections in structuring this relationship, which would result in an insufficient and/or a disorganization of the psychic functions. Therefore with this objective in mind, it was intended to show that skin disorders reflect a failure in the process of delimitation of the body limits due to the lack or inadequate maternal investments in the first years of life, hindering an experience of oneness and cohesion of internal and external processes. In the final part of the dissertation a clinical case is discussed according to the theoretical background covered in this work.

\section{Keywords}

Skin disorders; holding; separation-individuation; mother-child interation; body limits. 


\section{Sumário}

1.Introdução

2. O emergir do corpo na vivência infantil 13

2.1. Algumas considerações sobre o despertar da vida psíquica

2.2. O lugar dos cuidados maternos no desenvolvimento emocional Infantil 22

2.3. Rumo à diferença: o percurso da individuação 33

3. O lugar do adoecer na dinâmica da interação precoce

3.1. Sobre os males do corpo: uma visão psicossomática do adoecer a partir da Escola de Psicossomática Psicanalítica de Paris 43

3.2. Os destinos do corpo a partir da interação precoce 58

3.3. Interação mãe-filho e expressão da patologia psicossomática 62

4. Um olhar sobre a pele e suas manifestações 71

4.1. Os múltiplos sentidos da pele $\quad 71$

4.2. Pele: o primeiro revestimento psíquico 76

4.3. Uma pele para dois: considerações a partir do estudo de um caso clínico 